\title{
Collagen types in relation to expression of estradiol and progesterone receptors in equine endometrial fibrosis
}

\author{
Diego Lunelli ${ }^{1}$, Silvana Maris Cirio ${ }^{2}$, Selene C. Leite ${ }^{3}$, Carlos Eduardo Camargo ${ }^{4}$, \\ Luiz Ernandes Kozicki ${ }^{4 *}$ \\ ${ }^{1}$ Pontifical Catholic University of Paraná, Paraná, Brazil \\ ${ }^{2}$ Veterinary Medicine College, University Centrum of Evangelica, Curitiba, Brazil \\ ${ }^{3}$ Federal University of Paraná, Paraná, Brazil \\ ${ }^{4}$ Veterinary Medicine College, Pontifical Catholic University of Paraná, Paraná, Brazil \\ Email: dilunelli@hotmail.com, silvana.cirio@gmail.com, seleneleite@gmail.com, kaducamargo_vet@hotmail.com, \\ kkozicki.l@pucpr.br
}

Received 24 January 2013; revised 14 March 2013; accepted 15 April 2013

Copyright (C) 2013 Diego Lunelli et al. This is an open access article distributed under the Creative Commons Attribution License, which permits unrestricted use, distribution, and reproduction in any medium, provided the original work is properly cited.

\begin{abstract}
The aim of this study was to determine the influence of collagen I and III on the expression of estrogen and progesterone receptors in equine endometrial fibrosis. A total of 25 crossbred mares were studies. Two endometrial samples were collected from each mare, 1 in the estrus and 1 in the diestrus phase. The samples were classified according to histological changes. Collagen was typed and quantified using the picrosirius red histochemical technique, and steroid receptors were identified by immunohistochemistry. The results showed a predominance of collagen type III in all the endometrial samples. The expression of estrogen $\left(\mathrm{RE}_{2}\right)$ and progesterone $\left(\mathrm{RP}_{4}\right)$ receptors varied according to the estrous cycle. $R_{2}$ and $R_{4}$ expression varied in the estrus and diestrus phases; there was no influence of collagen I or II on receptor expression.
\end{abstract}

Keywords: Endometriosis; Mares; Picrosirius Red; Immunohistochemistry; Estradiol Receptors;

Progesterone Receptors

\section{INTRODUCTION}

Endometriosis is characterized by periglandular fibrosis of the endometrium [1], which compromises the integrity and function of the endometrial glands required for embryonic preimplantation and placental development [2]. Masseno (2012) [3] states that the fibroblasts that mediate fibrotic uterine glands in endometrosis shows strong immunoreactivity for myofibroblasts. These cells seem to be intermediate between fibroblasts and smooth muscle fibers, and are recognized as the main source of type

${ }^{*}$ Corresponding author.
I collagen and fibrogenic/inflammatory cytokines in the fibrotic lesions $[3,4]$.

The type of collagen presents in endometriosis characterizes the chronology of the condition. In repair and fibrotic processes, collagen type III is the first to be expressed, followed by replacement with type I collagen $[5,6]$. Picrosirius red is a technique used for collagen typing. It is distinguished by the intensity of the birefringence of optical fibers using polarized light microscopy. Different tones of color are observed according to the type of the molecular arrangement. Collagen type III appears green, while type I is yellow to red in color [7-9]. According to Schläfer (2007) [10], this histochemical method can be used to evaluate equine endometrial fibrosis. Using this technique, Nunes (2003) [11] demonstrated that collagen type I was the most frequent alteration in periglandular fibrosis.

The presence of endometrial fibrosis may compromise the expression of hormone receptors. Hoffmann et al. (2009) [12] demonstrated that stromal cells of periglandular fibrosis did not express hormone receptors properly. Aupperle et al. (2000) [13] stated that the expression of estrogen and progesterone receptors in fibrotic glands was lower when compared to areas unaffected by fibrosis.

Histopathological evaluation has been shown to be a useful tool in conjunction with immunohistochemistry, resulting in advances in diagnosis and prognosis of animals with fertility problems. Determination of the amount of fibrosis and detection of endometrial hormone recaptors in mares with a history of infertility may contribute to reproductive prognosis. The goal of the present study was to determine the areas of collagen type I and III present in equine endometrial fibrosis and to correlate the expression of the receptors of estrogen and progesterone 
during the estrus and diestrus phases.

\section{MATERIALS AND METHODS}

A total of 25 crossbred mares, aged 5 - 17 years, were used in this study. Two samples of endometrial epithelium were collected from each mare during the estrus and diestrus phases, and 50 biopsies were performed. Ovarian follicular control was carried out (palpation and transrectal ultrasonography) to identify the presence of follicles $35 \mathrm{~mm}$ to $40 \mathrm{~mm}$ in size (close to day 18 of the estrus cycle) to determine the ovulation day (D0). An endometrial biopsy was performed when 1 or more follicles (35 - $40 \mathrm{~mm}$ diameter) were observed on D8 postovulation. The biopsy procedure was as follows: "mouthto-alligator" type (Botupharma ${ }^{\circledR}$ ) biopsy forceps were transcervically inserted into the uterine body. Once they were in the body of the uterus, the clamp was inserted at the bifurcatio uteri. Deviations of approximately $5 \mathrm{~cm}$ into the left horn (= collection at estrus) and $5 \mathrm{~cm}$ to the right horn (= collection at diestrus) was conducted. Each fragment was about $2 \mathrm{~cm}$ long and $0.5 \mathrm{~cm}$ wide. After collection, the sample was fixed in Bouin's solution for 8 $\mathrm{h}$ and stored in $90 \%$ alcohol. The samples were processed using a standard protocol for histopathological evaluation.

The biopsy fragments were submitted to consecutive solutions of alcohol, cleared in xylol, impregnated in paraffin, and inserted in a rectangular mold of paraffin. The endometrium fragments were cut at $5 \mu \mathrm{m}$ thickness and colored in Harris's hematoxylin and eosin and Mallory's trichrome stains. For the histopathological evaluation, the endometrium samples were classified into categories according to Kenney and Doig (1986) [14].

\subsection{Histochemistry: Picrosirius Red}

Histological sections (4 $\mu \mathrm{m}$ thick) were prepared. The slides and sections were placed in tanks for staining and subjected to deparaffinization and hydration. The material was immersed in xylol $\left(60^{\circ} \mathrm{C}\right.$ for $\left.10 \mathrm{~min}\right)$, washed in running distilled water, and immersed in picrosirius red solution for $60 \mathrm{~min}$. Then, the slides were washed in distilled water and immersed in Harris hematoxylin solution for $10 \mathrm{~min}$. The material was then dehydrated, diaphanized, and mounted in synthetic resin $\left(\right.$ Entellan $\left.^{\circledR}\right)$.

The slides colored by picrosirius red were classified with respect to the quality of collagen by using a polarized light microscope (Olympus BX40). Collagen type III (fibrillar-immature) was identified by green refringence, while collagen type I (dense-mature) was identified by yellow-red refringence. Quantitative analysis was performed using images from 5 different fields from each slide (increased 200×), with a digital camera attached to the microscope. The images were stored and analyzed by DinoCapture ${ }^{\circledR}$ software and Image-Pro Plus ${ }^{\circledR}$, respec- tively. During the microscopic evaluation, the accumulation of collagen around individual glands and fibrotic nests was measured to determine the area of each type of collagen (I and III). The areas were obtained from 5 fields and stored for later correlation with the immunohistoche- mistry data.

\subsection{Immunohistochemistry}

For the immunohistochemical evaluation, 3- $\mu$ m-thick histological sections were prepared, positioned on pretreated blades with adhesive, and incubated at $60^{\circ} \mathrm{C}$ for $18 \mathrm{~h}$. Then, the slides were deparaffinized (10 min in xylol at room temperature) and then rehydrated in absolute ethanol and $80 \%$ alcohol for 10 min each. Antigenic recovery was then performed in Tris-EDTA (pH 9.0) at $96^{\circ} \mathrm{C}$ for $20 \mathrm{~min}$, followed by cooling at room temperature for 40 min.

Endogenous peroxidase activity was arrested by incubating the slides in perhydrol solution for 15 - $30 \mathrm{~min}$ followed by washing in distilled water. The histological section was incubated with the primary antibody for 12 $14 \mathrm{~h}$ (overnight) in a humid chamber at $4^{\circ} \mathrm{C}$, followed by washing with distilled water. The amplifier solution was applied, and the sections were incubated for $20 \mathrm{~min}$ at room temperature. The section was washed in distilled water, followed by incubation with the HRP polymer for $20 \mathrm{~min}$ at room temperature. The histological section was washed in distilled water and incubated with chromogen (DAB) for 3 - 20 min at room temperature for color development. A final wash was performed, and the slides were mounted. The primary antibody used to identify estrogen receptors (RE2) was clone 1D5 $\left(\right.$ Dako $\left.^{\circledR}\right)$, and clone Y85 (Cell Select ${ }^{\circledR}$ ) was used to identify progesterone (P4). Human placenta was used as the positive control.

For the quantitative and qualitative evaluation of steroid hormone receptor expression, different areas from the endometrium were analyzed (luminal epithelium, superficial and deep glandular epithelium, superficial and deep stromal cells), as recommended by Porto (2009) [15]. In addition, the glandular epithelium and stromal cells of fibrotic glands in the endometrium affected by endometrial fibrosis were also analyzed. Cells with a brown nucleus were considered positive for the expression of estrogen or progesterone receptors. The number of cells with this response was analyzed in 5 randomly selected fields for each region. The average of these fields was converted into a percentage. The color intensity of the positive cells observed in each field and the area evaluated were scored as absent, mild, moderate, or strong. Thirty cells in the luminal epithelium, 20 cells in the glandular epithelium, and 30 cells in the stromal surface (at $400 \times$ magnification) were counted, resulting in 150, 100, and 150 cells, respectively [15].

The present study was previously approved by the 
Ethics Committee on Animal Use of the Pontifícia Universidade Católica do Paraná.

\subsection{Statistical Analysis}

After collagen typing, the percentage of positive cells expressing steroid hormone receptors was determined. The data were interpreted, and differences were determined by Spearman correlation. To determine the type of collagen present in the endometrial fibrosis in each category, Student's $t$ test was used. The significance level for variables was 5\% ( $\alpha=0.05)$. The calculations were performed by the statistical software GraphPad Prism version 3.00 for Windows (San Diego, CA, USA).

\section{Results and Discussion}

We evaluated 50 samples of equine endometrial biopsies according to the criteria (amount of fibrosis in the sample, which is composed of collagen type I and type III) of Kenney and Doig (1986) [14]. Twenty-five samples were collected in the estrus phase: 6 were classified into category I (24\%), 13 were in II (52\%), and 6 were in category IIB (24\%). Twenty-five samples were collected in the diestrus phase: 6 were classified into category I (24\%), 14 were in II (56\%), and 5 were in category IIB (20\%). No sample was classified into category III. The results of the sample classification are shown in Tables 1 and 2.

Classification of the endometrial samples collected at different phases of the estrous cycle differed. Among the

Table 1. Distribution of equine endometrium samples (estrus phase) classified according to Kenney and Doig (1986) $(n=25)$.

\begin{tabular}{ccc}
\hline Category & Samples (n) & Incidence (\%) \\
\hline I & 6 & 24 \\
IIA & 13 & 52 \\
IIB & 6 & 24 \\
III & 0 & 0 \\
Total & 25 & 100 \\
\hline
\end{tabular}

Table 2. Distribution of equine endometrium samples (diestrus phase) classified according to Kenney and Doig (1986) ( $\mathrm{n}=$ 25).

\begin{tabular}{ccc}
\hline Category & Samples (n) & Incidence (\%) \\
\hline I & 6 & 24 \\
IIA & 14 & 56 \\
IIB & 5 & 20 \\
III & 0 & 0 \\
Total & 25 & 100 \\
\hline
\end{tabular}

25 mares, 18 received the same classification, independent of the phase in which the sample was collected. Seven mares were classified differently according to the estrous cycle: 3 mares classified as class IIB in the endometrial samples collected in the estrus phase were reclassified as IIA in the diestrus phase; 2 mares classified as class II in the estrus phase were reclassified as class I in the diestrus phase; 1 mare classified as class I in the estrus phase was reclassified as class II in the diestrus phase; and 1 mare classified as class I in the estrus phase was reclassified as class IIB in the diestrus phase.

Kenney (1975) [16] stated that endometrial samples cover only $0.1 \%$ of the entire surface of the endometrium and are only representative when the pathological changes are diffusely distributed $[17,18]$. However, Keller et al. (2006) [19] reported that an endometrial biopsy cannot be representative when endometrial fibrosis is considered separately. These researchers evaluated the effect of several experimental infections in the development of endometrial fibrosis over short periods and observed large variations in the categories. In a study over 12 months, 9 mares showed variations in 2 categories, and 10 showed variations in 3 categories. The classifications were superior (worse) or inferior (better) categories; some categories were observed over an interval of 10 days to detect changes. Recently Fiala et al. (2010) [20] reported that the place where the endometrial sample is obtained influences the categorization, confirming the hypothesis that a single endometrial biopsy may not be representative when only endometrial fibrosis is considered.

\subsection{Histochemistry-Picrosirius Red}

Borges et al. (2007) [9] stated that picrosirius red staining is a useful method for distinguishing the arrangement of collagen and may be related to the molecular structure of collagen. In this study, histochemistry with picrosirius red allowed the identification of the fibrosis focus, as well as the classification and quantification of collagen (Figure 1).

After classification into categories, all the endometrial samples showed a predominance of the type III collagen, with statistical differences ( $p<0.01$ ) in the samples collected during diestrus and those classified into categories IIA and IIB, when compared with collagen I. Bochsler and Slauson (2002) [6] stated that the deposition of collagen types I and III occurs in fibrotic processes, which promotes the development of cicatricial tissues with major tensile strength. Type III collagen (predominant in healthy endometrium) is gradually replaced by collagen type I, which occurs with increasing fibrotic changes [21, 22]. According to Walter et al. (2001) [23], levels of collagen type I do not increase in the endometrium of mares with severe fibrosis; the proportion of collagen I is 


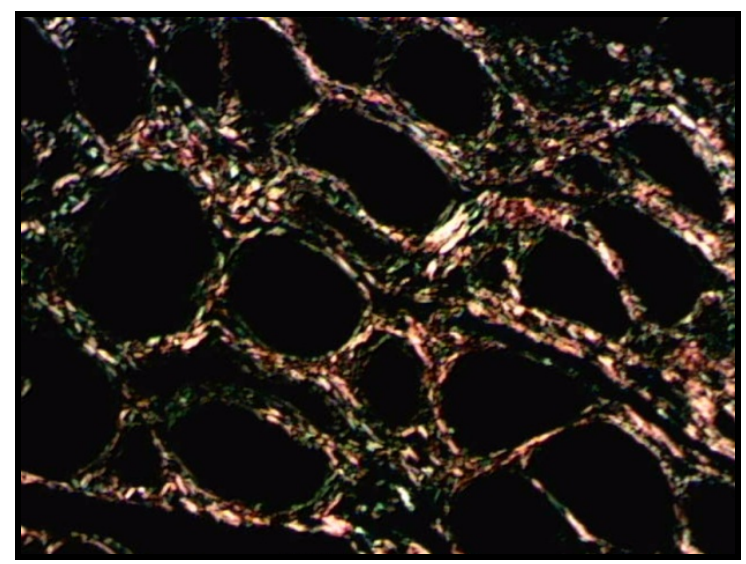

(a)

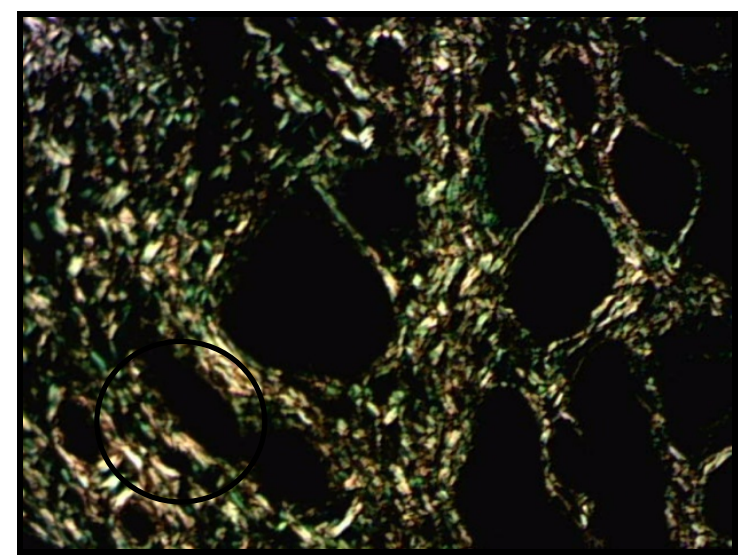

(b)

Figure 1. Distribution of collagen in equine endometrium (diestrus phase) with picrosirius red staining. (a) Type I (red) and type III (green); (b) Type I (yellow) and type III (green); Magnification: 200×.

similar to that found in the healthy endometrium. On the other hand Masseno (2009) [22] verified that the type I collagen predominated in the endometrium showed sharper grades of lesion, focusing in fibrotic periglandular lesions.

\subsection{Immunohistochemistry}

Immunohistochemistry allows the identification of different proteins and their expression site (physiological or pathological processes) in tissues. In addition, it is useful for identification of the molecular mechanisms involved in the maintenance or breakdown of tissue homeostasis [15].

In the present study, RE2, and RP4 were investigated in the estrus and diestrus phases. The superficial and deep cells of the uterine stroma presented moderate to strong expression of progesterone and estrogen receptors in the estrus phase, whereas deep glands showed no such response (Figure 2(a)). In the diestrus phase, the expression of steroid hormone receptors was observed in the

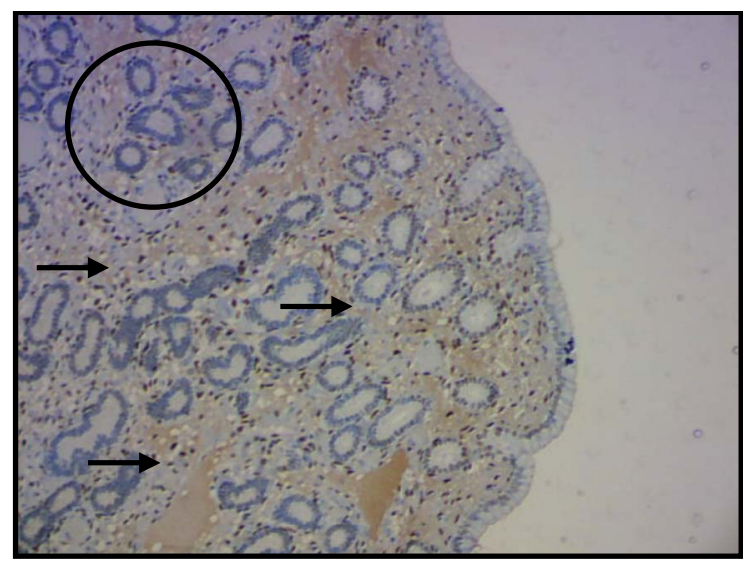

(a)

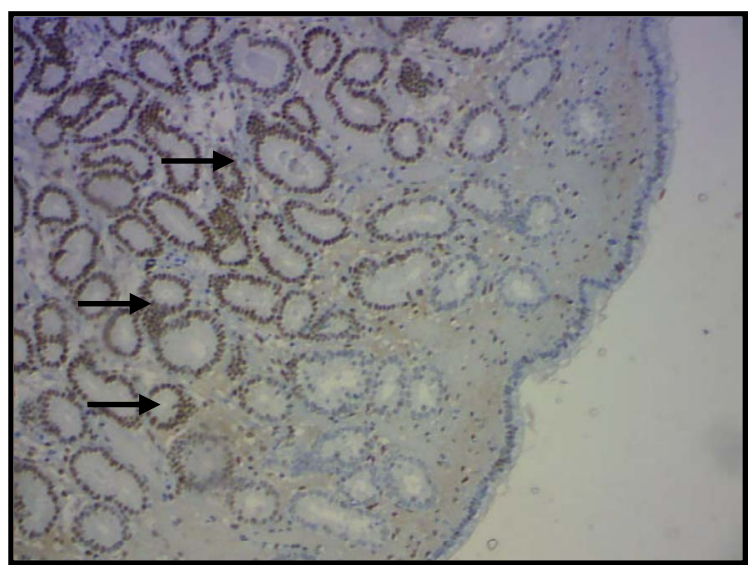

(b)

Figure 2. Identification of equine endometrial progesterone receptors by immunohistochemistry. (a) No expression in deep glands (circle), and an intense response in the superficial and deep stromal cells (arrows) in the estrous phase; (b) Evident expression in the deep glands (arrows) in the diestrus phase; Magnification: 100×.

glandular epithelium with sharp intensity (Figure 2(b)). According to Watson et al. (1992) [24], progesterone receptors are most intensely expressed in the stroma (estrus phase), whereas the expression of steroid hormone receptors is evident in the glandular epithelium in the diestrus phase [13], which differs from the findings of the present study for this phase.

The expression of estrogen and progesterone hormones results in cell proliferation and differentiation of the endometrium [25], which may be due to the presence of high-affinity receptors that can be identified by immunohistochemical techniques [26] during the estrus phase by brown coloration of the nucleus in the cells positive for steroid receptors. In this study, in the estrus and diestrus phases, the percentage of positive cells remained stable for the steroid hormone receptors. A median percentage of colored cells in the deep glandular epithelium and lower percentages in the luminal and in super- 
ficial glandular epithelium were observed (Figure 3).

Aupperle et al. (2000) [13] reported greater expression of steroid hormone receptors in the estrus phase that showed a lower expression during the diestrus phase, which was due to estrogen stimulation that increased the expression of estrogen and progesterone receptors [24]. On the fifth day after ovulation, expression of progesterone receptors was shown to reach a maximum, then was observed to decrease until the end of diestrus, and then increase again at the beginning of the new estrus phase [13].

Periglandular fibrosis and fibrotic nests influenced the expression of the hormone receptors, thereby showing that these fibrotic changes in the endometrium did not interfere with hormone expression (Figure 4(a)) or affect this hormone expression (Figure 4(b)). Hoffmann et al. (2009) [12] reported that stromal cells of periglandular fibrosis express hormone receptors insufficiently. As a result, these cells cannot respond to endocrine cyclic stimuli, making them independent of the hormonal control of the uterus. Similar findings were reported by Aupperle et al. (2000) [13], who stated that expression of estrogen and progesterone receptors in the fibrotic glands was lower when compared with areas not affected by fib-

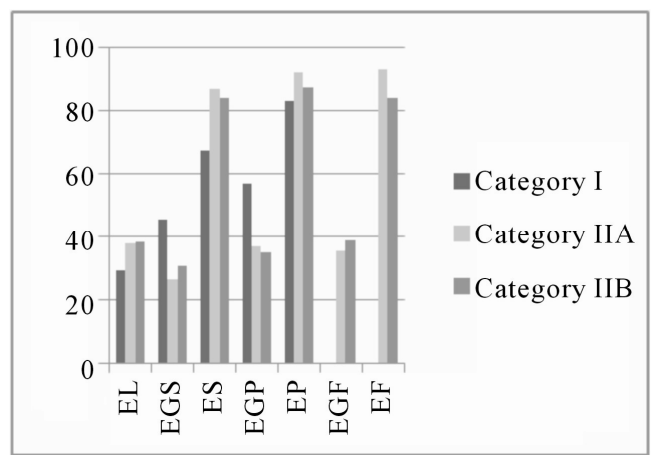

(a)

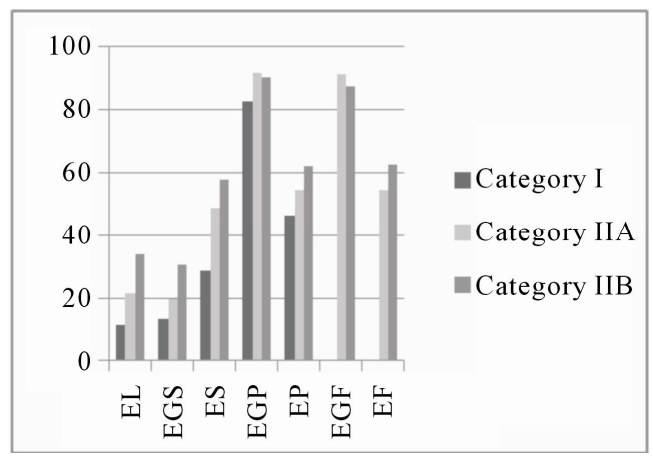

(c) rosis.

\subsection{Influence of Collagen Type Present in Endometrial Fibrosis on Steroid Receptor Expression}

We did not observe any difference among the affected endometrial fibrosis areas and the type of collagen. We hypothesized that the heterogeneity of the available samples may have affected the results; furthermore, none of the samples were classified in category III. Endometria with this classification show extensive areas of fibrosis uniformly distributed among the endometrial glands, which can directly influence the expression of the steroid hormone receptors.

Hoffmann et al. (2009) [12] report the early stages of fibrosis are characterized by some alterations in the basal membrane and focal accumulation of stromal cells able to synthetize collagen fibers. Fibrosis is the main component of tissue reaction. It is very important to determine the arrangement, placement, and composition of the fibrotic nests to evaluate the degree of involvement of the endometrium and the likelihood of regression of the previously established lesion [11]. However, it is known

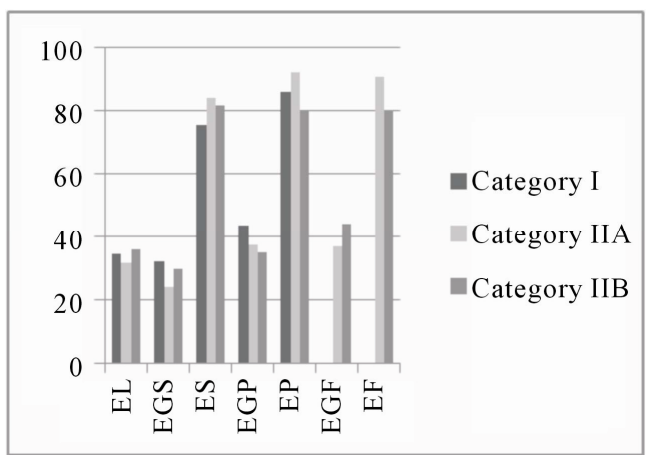

(b)

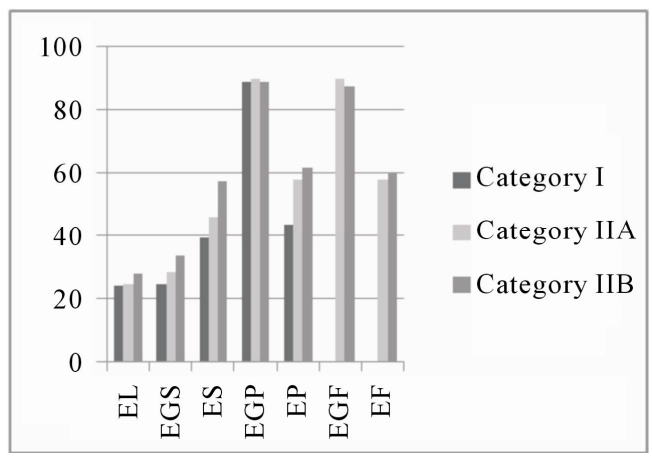

(d)

Figure 3. Mean percentage of steroid receptors in the estrous cycle. Areas of the equine endometrium in different categories according to the classification of Kenney and Doig (1986). (a) Estrogenic receptors in the estrus phase; (b) Receptors for progesterone in the estrus phase; (c) Estrogen receptors in the diestrus phase; (d) Receptors for progesterone in the diestrus phase. EL: luminal epithelium; EGS: superficial glandular epithelium; ES: superficial stroma; EGP: deep glandular epithelium; EP: deep stroma; EGF: glandular epithelium with fibrosis; EF: stromal fibrosis. 


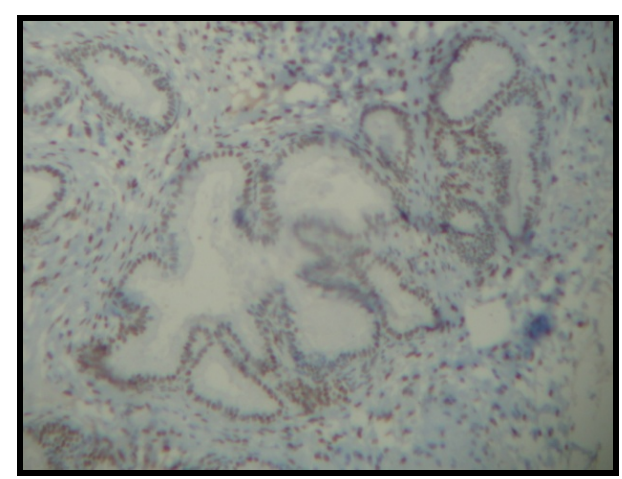

(a)

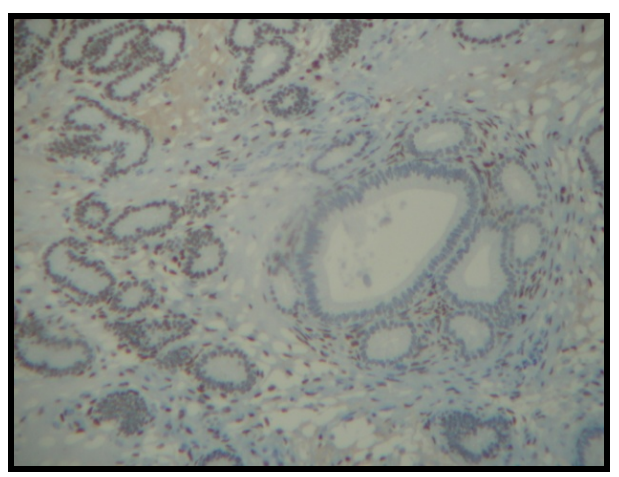

(b)

Figure 4. Expression of equine endometrial progesterone receptors by immunohistochemistry. (a) Hormone expression in fibrotic nests (arrows); (b) Absence of glandular hormone expression in endometrial fibrosis (arrows). Magnification: 400×.

that once endometrial fibrosis is initiated, it becomes progressive and irreversible even in the absence of continued injury [27]. Thus, as endometriosis progresses, it will reduce the quantity of endometrial glands, resulting in endometrial atrophy [14]. In addition, glands with fibrotic involvement express less estrogen and progesterone receptors than areas not affected by fibrosis [13].

In a recent study, Masseno (2012) [3] found that the arrangement of collagen fibers is related to the type of the process evolution. The myofibroblasts are directly related to collagen deposition in the regions where they are present. In active endometrosis predominates the reticular arrangement of collagen (type III) and in active or inactive destructive endometriosis predominates the type I, based on morphological endometriosis classification [12], no relating although the type of steroid recaptor in endometriosis expression.

\section{CONCLUSION}

We conclude that there was a predominance of collagen type III in all the endometrial samples, independent of the sample classification category. The expression of the receptors for estrogen and progesterone varied in the estrus and diestrus phases. There was no influence of collagen type I or III on both endometrial fibrosis and the expression of estrogen and progesterone receptors. Picrosirius red histochemistry could identify and quantify endometrial fibrosis in mares; therefore, it may be useful as a complementary method for the diagnosis and prognosis of equine infertility.

\section{REFERENCES}

[1] Kenney, R.M. (1978) Cyclic and pathologic changes of the mare endometrium as detected by biopsy, with a note on embryonic death. Journal of the American Veterinary Medical Association, 172, 241-262.

[2] Gray, C.A., Bartol, F.F., Tarleton, B.J., Wiley, A.A., John- son, G.A., Bazer, F.W. and Spencer, T.E. (2001) Developmental biology of uterine glands. Biological Reproduction, 65, 1311-1323. doi:10.1095/biolreprod65.5.1311

[3] Masseno, A.P.B. (2012) Avaliação da fibrose endometrial e dos miofibroblastos na endometroses ativa e inativa das éguas. Tese (doutorado)—Faculdade de Medicina Veterinária e Zootecnia, Universidade Estadual Paulista, Botucatu, 2012.

[4] Guyot, C., Lepreux, S., Combe, C., Doudnikoff, E., Bioulac-Sage, P., Balabaud, C. and Desmouliére, A. (2006) Hepatic fibrosis and cirrhosis: The (myo)fibroblastic cell subpopulations involved. International Journal of Biochemistry and Cell Biology, 38, 135-151.

[5] Martinez-Hernandez, A. (1999) Repair, regeneration and fibrosis. In: Rubin, E. and Faber, J.L., Eds., Pathology, 3rd Edition, Lippincot-Raven, Philadelphia.

[6] Bochsler, P.N. and Slauson, D.O. (2002) Inflammation and repair of tissue. In: Slauson, D.O. and Cooper, B.J., Eds., Mechanisms of Disease: A Textbook of Comparative General Pathology, 3rd Edition, Mosby, St. Louis, 140-245.

[7] Junqueira, L.C.U., Cossermelli, W. and Brentani, R.R. (1978) Diferencial staining of collagens type I, II and III by Sirius Red and polarization microscopy. Archives of Histology of Japan, 41, 267-274. doi:10.1679/aohc1950.41.267

[8] Montes, G.S. and Junqueira, L.C.U. (1991) The use of the picrosirius-polarization method for the study of the biopathology of collagen. Memórias do Instituto Oswaldo Cruz, 86, 1- 11. doi:10.1590/S0074-02761991000700002

[9] Borges, L.F., Gutierrez, P.S., Marana, H.R.C. and Taboga, S.R. (2007) Picrosirius-polarization staining method as an efficient histopathological tool for collagenolysis detection in vesical prolapsed lesions. Micron, 38, 580-583. doi:10.1016/j.micron.2006.10.005

[10] Schlafer, D.H. (2007) Equine endometrial biopsy: Enhancement of clinical value by more extensive histopathology and application of new diagnostic techniques? Theriogenology, 68, 413-422. doi:10.1016/j.theriogenology.2007.04.040

[11] Nunes, L.C. (2003) Avaliação histopatológica, histoquímica, imunohistoquímica e morfométrica das endometrites 
crônicas em éguas. Dissertação (mestrado)—Faculdade de Medicina Veterinária e Zootecnia, Universidade Estadual Paulista, Botucatu.

[12] Hoffmann, C., Ellenberger, C., Mattos, R.C., Aupperle, H., Dhein, S., Stief, B. and Schoon, H.A. (2009) The equine endometrosis: New insights into the pathogenesis. Animal Reproduction Science, 111, 261-278. doi:10.1016/j.anireprosci.2008.03.019

[13] Aupperle, H., Ozgen Schoon, H.A., Schoon, D., Hoppen, H.O., Sieme, H. and Tannapfel, A. (2000) Cyclical endometrial steroid hormone receptor expression and proliferation intensity in the mare. Equine Veterinary Journal, 32, 228-232. doi:10.2746/042516400776563554

[14] Kenney, R.M. and Doig, P.A. (1986) Equine endometrial biopsy. In: Morrow, D.A., Ed., Current Therapy in Theriogenology, W.B. Saunders, Philadelphia, 723-729.

[15] Porto, C.D. (2009) Expressão de TGF- $\beta 1$, metaloproteinases e avaliação dos índices de proliferação celular e apoptótico nas endometrites crônicas das éguas. Tese (doutorado)—Faculdade de Medicina Veterinária e Zootecnia, Universidade Estadual Paulista, Botucatu.

[16] Kenney, R.M. (1975) Prognostic value of endometrial biopsy of the mare. Journal of Reproduction and Fertility, 23, 347-348.

[17] Bergman, R.V. and Kenney, R.M. (1975) Representativeness of a uterine biopsy in the mare. Proceedings AAEP, 355-361.

[18] Waelchli, R.O. and Winder, N.C. (1989) Distribution of histological lesions in the equine endometrium. Veterinary Record, 124, 274-276. doi:10.1136/vr.124.11.271

[19] Keller, A., Neves, A.P., Aupperle, H., Steiger, K., Garbade, P., Schoon, H.A., Klug, E. and Mattos, R.C. (2006) Repetitive experimental bacterial infections do not affect the degree of uterine degeneration in the mare. Animal Reproduction Science, 94, 276-279. doi:10.1016/j.anireprosci.2006.04.012

[20] Fiala, S., Esmeraldino, A.M.T., Jobim, M.I.M., Garbade, P.,
Wolf, C.A., Richter, G., Gregory, R.M. and Mattos, R.C. (2010) Endometrial fibrotic changes. Is one biopsy enough to diagnose degenerative changes? Animal Reproduction Science, 121, 89-90. doi:10.1016/j.anireprosci.2010.04.133

[21] Porto, C.D. (2006) Caracterização histoquímica do colágeno e expressão de MMP-2, MMP-9 e TIMP-1 nas endometrites crônicas das éguas. Dissertação (mestrado)Faculdade de Medicina Veterinária e Zootecnia, Universidade Estadual Paulista, Botucatu.

[22] Masseno, A.P.B. (2009) Caracterização imunoistoquímica dos miofibroblastos endometriais e da expressão de MMP-2 nas endometrites crônicas das éguas. Dissertação (mestrado)—Faculdade de Medicina Veterinária e Zootecnia, Universidade Estadual Paulista, Botucatu.

[23] Walter, I., Handler, J., Reifinger, M. and Aurich, C. (2001) Association of endometrosis in horses with differentiation of periglandular myofibroblasts and changes of extracellular matrix proteins. Reproduction, 121, 581-586. doi:10.1530/rep.0.1210581

[24] Watson, E.D., Skolnik, S.B. and Zanecosky, H.G. (1992) Progesterone and estrogen receptor distribution in the endometrium of the mare. Theriogenology, 38, 575-580. doi:10.1016/0093-691X(92)90020-R

[25] Clark, J.H., Scrader, W.T. and O’Malley, B.W. (1985) Mechanisms of steroid hormone action. In: Witson, J.D. and Fortec, D.W., Eds., Textbook of Endocrinology, W.B. Saunders, Philadelphia, 33-75.

[26] Tomanelli, R.N., Sertich, P.L. and Watson, E.D. (1991) Concentrations of oestrogen and progesterone receptor in the endometrium of the mare. Journal of Reproduction \& Fertility, 44, 267-273.

[27] Ricketts, S.W. and Alonso, S. (1991) The effect of age and parity on the development of equine chronic endometrial disease. Equine Veterinary Journal, 23, 189-192. doi:10.1111/j.2042-3306.1991.tb02752.x 